\title{
PELATIHAN PEMBUATAN BURIDOR (BUBUR INSTAN DAUN KELOR) SEBAGAI MP-ASI B2SA DI DESA TANJUNG KECAMATAN MANGLI KABUPATEN JEMBER
}

\author{
Anna Mardiana Handayani1 ${ }^{\# 1}$, Faradila Nurintan Firdaus ${ }^{* 2}$, Frieska Fatima Aziz ${ }^{* 3}$, Yoga Eka Birnanda ${ }^{* 4}$, \\ Rara Anggi Dewanti ${ }^{* 5}$, Dwi Nur Azizah ${ }^{* 6}$ \\ \# Jurusan Teknologi Pertanian, Politeknik Negeri Jember \\ Jalan Mastrip Kotak Pos 164, Jember \\ ${ }^{1}$ anna.mardiana@polije.ac.id \\ *Jurusan Teknologi Pertanian, Politeknik Negeri Jember \\ Jalan Mastrip Kotak Pos 164, Jember \\ ${ }^{2}$ faradilanurintan@gmail.com \\ 3 frieskafatimaa@gmail.com \\ 4yogaeka19@gmail.com \\ 5raraanggi01@gmail.com \\ 6dwinurazizah99@gmail.com
}

Abstrak

Kegiatan Pengabdian Kepada masyarakat ini bertujuan untuk meningkatkan gizi balita dengan MP-ASI yang B2SA. Hal ini dilakukan dengan Pelatihan Pembuatan BURIDOR (bubur instan daun kelor). Pembuatan MP-ASI BURIDOR ini merupakan keinginan dari beberapa mitra untuk mencoba inovasi baru dengan mengolah daun kelor menjadi bubur instan, mengingat mayoritas penduduk menanam pohon kelor. MP-ASI dalam bentuk kemasan instan sangat praktis dibawa kemana saja dan dalam keadaan sibuk. Namun, orang tua terkadang khawatir dengan makanan praktis yang beresiko mengandung garam tinggi, mengandung bahan pengawet dan bahan tambahan makanan lain yang berbahaya bagi balita.

Salah satu daerah yang mengalami permasalahan tersebut yaitu Desa Tanjung Kecamatan Mangli yang merupakan daerah kurang produktif dan memiliki posyandu yaitu posyandu Aster 54 A. Selain itu di Desa Tanjung mayoritas penduduknya memiliki lahan pekarangan yang ditanami pohon kelor. Banyak orang tua yang memiliki bayi tetapi kurang paham manfaat dari pentingnya pemberian MP-ASI yang B2SA (beragam, bergizi, seimbang dan aman).

Hasil yang telah dicapai berdasarkan indikator keberasilan jangka pendek selama 5 bulan yaitu telah dilakukannya program pengabdian yang membuat ibu rumah tangga khususnya yang memiliki balita mendapat pengetahuan yang lebih banyak tentang pentingnya MP-ASI, masyarakat di Desa Tanjung dapat memanfaatkan hasil bumi (daun kelor)

menjadi MP-ASI BURIDOR, serta mendemonstrasikan pembuatan MP-ASI yang B2SA (beragam, bergizi, seimbang dan aman) yaitu bubur instan daun kelor.

Pengabdian kepada masyarakat tentang pelatihan pembuatan buridor yaitu masyarakat di Desa Tanjung dapat meningkatkan pengetahuan ibu-ibu tentang pentingnya pemberian MP-ASI, membuat MP-ASI yang inovasi, tanpa bahan pengawet dan B2SA yaitu BURIDOR serta dapat memanfaatkan tanaman lokal.

Keywords : MP-ASI, daun kelor

\section{PENDAHULUAN}

I.

MP-ASI merupakan proses transisi dari asupan yang semata berbasis susu menuju ke makanan yang semi padat. Pengenalan dan pemberian makanan pendamping ASI harus dilakukan secara bertahap, baik bentuk maupun jumlahnya disesuai dengan kemampuan pencernaan bayi tersebut. Pengenalan dan pemberian makanan pendamping ASI yang tepat diharapkan tidak hanya dapat memenuhi gizi bayi, namun juga merangsang keterampilan makan dan merangsang rasa percaya diri bagi bayi. Pemberian makanan tambahan harus bervariasi dari bentuk bubur cair ke bentuk bubur kental, sari buah, buah segar, makanan lumat, makanan lembek dan akhirnya makanan padat. ${ }^{1} \quad$ Perlunya perhatian lebih, dalam tumbuh kembang di usia balita didasarkan fakta bahwa kurang gizi yang terjadi pada masa emas ini dapat bersifat irreversible (tidak 
dapat pulih). Sebagian besar kejadian kurang gizi dapat dihindari apabila mempunyai cukup pengetahuan tentang cara pemeliharaan gizi dan mengatur makanan anak. MP-ASI dalam bentuk kemasan instan sangat praktis untuk dibawa kemana saja dan dalam keadaan sibuk sekalipun karena dapat diolah dengan waktu yang singkat. Namun, orang tua terkadang juga khawatir dengan makanan praktis yang beresiko mengandung garam tinggi, mengandung bahan pengawet dan bahan tambahan makanan lain yang berbahaya bagi bayi. Pemberian MP-ASI pada anak dianjurkan memenuhi syarat B2SA yaitu bergam, bergizi, seimbang dan aman. Makanan pendamping ASI berbahan dasar daun kelor yang dibuat instan dapat dijadikan inovasi baru untuk mengatasi permasalahan yang dikhawatirkan oleh orang tua. Menurut Anonim (2017), bayi di atas 6 bulan bisa diberikan daun kelor tetapi dalam bentuk serbuk. Menurut hasil penelitian, daun kelor mengandung vitamin $\mathrm{A}$, vitamin $\mathrm{B}$, vitamin $\mathrm{C}$, kalsium, kalium, besi dan protein dalam jumlah sangat tinggi yang dapat mudah dicerna dan diasimilasi oleh tubuh manusia (Radiyanthi,2015). Daun kelor memiliki kandungan kalsium yang lebih banyak dari pada susu, lebih banyak zat besi dari pada bayam, lebih banyak protein dari pada pisang. Daun kelor mengandung sejumlah asam amino dan flavonoid. Asam amino yang terkandung diduga dapat meningkatkan sistem imun, hal tersebut dapat meningkatkan kekebalan tubuh anak dan akan bisa membantu tubuh untuk melawan bakteri biasa, sedangkan flavonoid berfungsi sebagai antioksidan yang mampu menjaga terjadinya oksidasi sel tubuh, kandungan flavonoid dapat mencegah peroksidasi lemak (Widowati, 2014). Berdasarkan permasalahan mitra PKM maka persoalan prioritas yang disepakati untuk diselesaikan selama program PKM adalah "Pelatihan Pembuatan Buridor (Bubur Instan Daun Kelor) sebagai MP-ASI B2SA di Desa Tanjung Kecamatan Mangli Kabupaten Jember". 2

\section{TARGET DAN LUARAN}

Sasaran pengabdian masyarakat kami adalah ibu-ibu rumah tangga yang mempunyai balita di Desa Tanjung Kec. Mangli. Pengabdian ini dilakukan dengan pelatihan pembuatan MP-ASI yang B2SA. Luaran yang diharapkan dengan pelaksanaan program ini adalah MP-ASI Buridor yang siap saji dapat dimanfaatkan sebagai MP-ASI balita di Desa Tanjung, Kecamatan Mangli, kabupaten Jember, memberi MP-ASI yang B2SA (beragam, bergizi, seimbang dan aman) dan praktis untuk tumbuh kembang balita. Selain itu, juga diharapkan dapat menanamkan pola pikir orang tua untuk mengkampanyekan pemanfaatan hasil bumi daun kelor berupa Buridor dan modul sebagai pedoman pembuatan BURIDOR.

\section{METODE PELAKSANAAN}

Metode Pengabdian

1) Koordinasi dengan ketua posyandu

2)Melakukan pertemuan dengan ibu-ibu rumah tangga sebanyak $2 x$ pertemuan (minggu pertama dan ketiga)

3) Pada pertemuan pertama ibu-ibu mengisi kuisioner sebelum dan sesudah melakukan pelatihan dan pemberian materi.

4) Pemberian materi menggunakan power point, pemutaran video mengenai MP-ASI.

5) Implementasi pembelajaran modul dan praktek membuat BURIDOR pada minggu pertama

6) Pada pertemuan kedua ibu-ibu praktik membuat BURIDOR secara mandiri

7) Evaluasi (feed back) yang diperoleh oleh ibu-ibu an pelatihan pembuatan BURIDOR

\section{HASIL DAN PEMBAHASAN}

Dari hasil pengamatan pada implementasi kegiatan pegabdian pelatihan pembuatan BURIDOR menunju

1. Koordinasi dengan ketua posyandu dilakukan pada bulan Maret dimana koordinasi dilakukan dengan menemui ketua Posyandu membahas kegiatan pelaksanaan PKM. Koordinasi selanjutnya kami menemui ketua RT desa Tanjung untuk meminta izin pelatihan pada ibu-ibu. Hasil yang didapat yaitu ketua posyandu dan ketua RT mengizinkan serta sangat antusias menyambut adanya kegiatan tersebut .

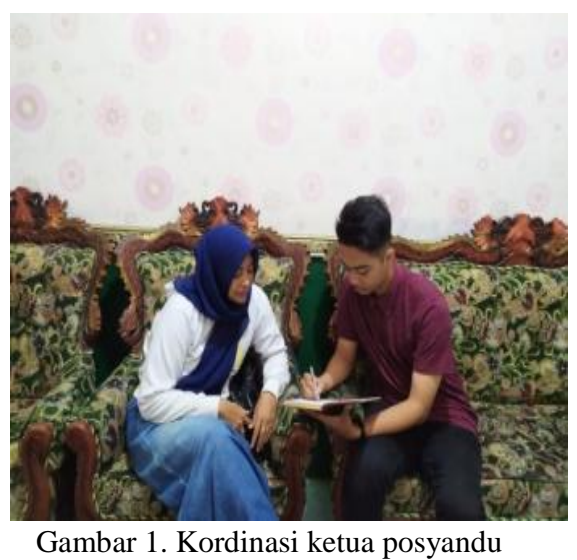

2. Pertemuan diagendakan sebanyak $2 x$ dimana pada pertemuan 1 akan diadakan demonstrasi mengenai pentingnya pemberian MP-ASI serta proses pembuatan BURIDOR. Sedangkan pada 
pertemuan ke-2 ibu-ibu membuat BURIDOR secara mandiri sambil didampingi oleh kami.

3. Pertemuan pertama ibu-ibu mengisi kuisioner sebelum dan sesudah acara. Hasil yang didapatkan terlihat pada gambar X menunjukkan bahwa jumlah peserta yang hadir sebanyak 14 orang. Pengetahuan tentang MP-ASI menunjukkan sebelum pelatihan 6 peserta mengetahui tentang MP-ASI dan terjadi peningkatan setelah dilakukan kegiatan sebanyak 10 peserta. Pengetahuan pengertian MP-ASI menunjukkan sebelum pelatihan 5 peserta mengetahui pengertian MP-ASI dan terjadi peningkatan setelah dilakukan kegiatan sebanyak 10 peserta. Pengetahuan pentingnya pemberian MP-ASI menunjukkan bahwa sebelum kegiatan 4 peserta mengetahui pentingnya pemberian MP-ASI dan terjadinya peningkatan setelah dilakukan kegiatan sebanyak 10 peserta. Pengetahuan usia pemberian MP-ASI menunjukkan bahwa sebelum kegiatan 5 peserta mengetahui usia pemberian MP-ASI dan terjadi peningkatan setelah dilakukan kegiatan sebanyak 11 peserta. Pengetahuan Makanan pertama kali untuk bayi berusia lebih dari 6 bulan menunjukkan bahwa sebelum kegiatan 8 peserta mengetahui makanan pertama kali untuk bayi berusia lebih dari 6 bulan dan terjadi peningkatan setelah dilakukan kegiatan sebanyak 13 peserta. Pengetahuan makanan yang diberikan pada bayi berusia lebih dari 6 bulan menunjukkan bahwa 8 peserta mengetahui Makanan yang diberikan pada bayi berusia lebih dari 6 bulan dan terjadi peningkatan setelah dilakukan kegiatan sebanyak 13 peserta. Pengetahuan berapa kali sehari pemberian MP-ASI menunjukkan bahwa 6 peserta mengetahui berapa kali sehari MP-ASI diberikan dan terjadi peningkatan setelah dilakukan kegiatan sebanyak 12 peserta. Pengetahuan tentang alasan dibutuhkannya MP-ASI menunjukkan bahwa 8 peserta mengetahui alasan dibutuhkannya MP-ASI dan terjadi peningkatan setelah dilakukan kegiatan sebanyak 13 peserta. Pengetahuan tentang usia pemberian nasi tim yang tepat pada bayi menunjukkan bahwa 8 peserta mengetahui usia yang tepat pemberian nasi tim pada bayi dan terjadi peningkatan setelah dilakukan kegiatan sebanyak 13 peserta. Pengetahuan usia pemberian biskuit dan buahbuahan pada bayi menunjukkan bahwa 6 peserta mengetahui usia yang tepat pemberian biskuit dan buah-buahan pada bayi dan terjadi peningkatan setelah dilakukan kegiatan sebanyak 12 peserta. Pengetahuan menunda makanan tambahan dapat mengurangi resiko alergi makanan menunjukkan bahwa 4 peserta mengetahui menunda makanan tambahan dapat mengurangi resiko alergi makanan dan terjadi peningkatan setelah kegiatan sebanyak 10 peserta. Pengetahuan usia bayi disapih menunjukkan sebanyak 7 peserta yang mengetahui usia bayi disapih dan terjadi peningkatan setelah kegiatan sebanyak 13 peserta

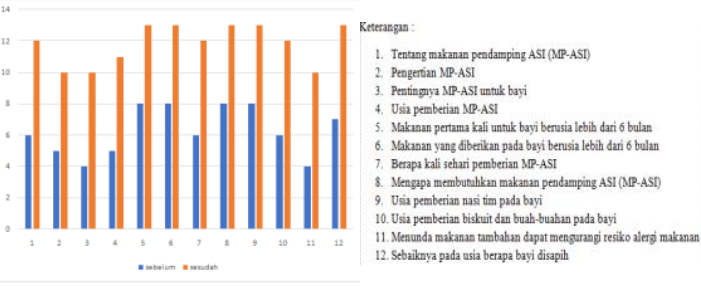

Gambar 2. Diagram hasil kuisioner

4. Pemberian materi menggunakan power point dan pemutaran video mengenai MP-ASI, meteri yang diberikan berupa pemahaman MP-ASI, pembuatan MP-ASI BURIDOR serta pengetahuan penyimpanan produk MP-ASI BURIDOR. Pemutaraan video mengenai MP-ASI bertujuan agar ibu-ibu memahami secara audiovisual melalui putaran video tersebut.

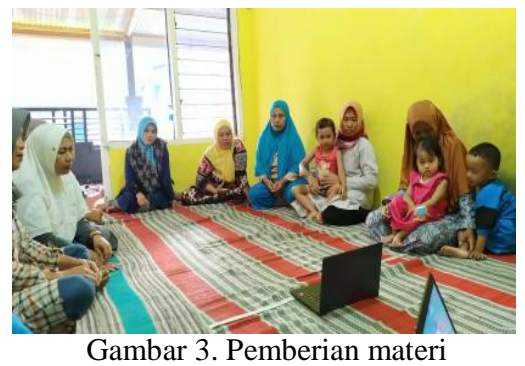

5. Implementasi pembelajaran modul dan praktek membuat BURIDOR pada minggu pertama dihadiri dengan 14 peserta ibu-ibu. Beberapa ibu-ibu secara kritis bertanya sambil melihat proses pembuatan BURIDOR

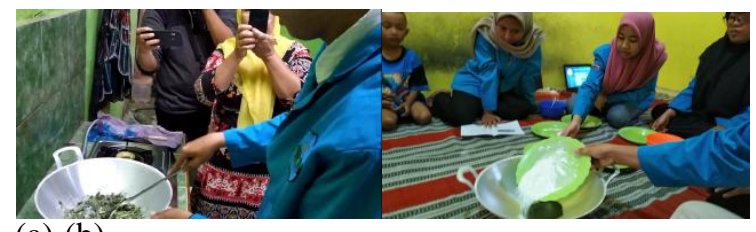

(a) (b)

Gambar 4. (a),(b). proses pembuatan

6. Pada pertemuan 2 ibu-ibu praktik membuat BURIDOR secara mandiri, pertemuan ke 2 akan dilakukan pada 7 Juli 2019.

7. Evaluasi (feed back) berupa video manfaat pelatihan yang didapatkan serta kesan dan pesan dari ibu-ibu dan juga kader posyandu yang berisi tentang masalah yang ada.

\section{KESIMPULAN}

Pengabdian kepada masyarakat tentang pelatihan pembuatan buridor yaitu masyarakat di Desa 
Tanjung dapat meningkatkan pengetahuan ibu-ibu tentang pentingnya pemberian MP-ASI, membuat MP-ASI yang inovasi, tanpa bahan pengawet dan B2SA yaitu BURIDOR serta dapat memanfaatkan tanaman lokal.

\section{UCAPAN TERIMA KASIH}

Pengabdian Masyarakat dilaksanakan dengan dana dari Direktorat Ristekdikti.

\section{DAFTAR PUSTAKA}

[1] Aminah, Syarifah et. al. 2015. Kandungan Nutrisi dan Sifat Fungsional Tanaman Kelor. Buletin Pertanian Perkotaan Volume 5 Nomor 2 35-44

[2] Khasanah, Ainull. 2017. Formulasi Bubur Daun Kelor Instan. https://www.scribd.com/document/353717976/FormulasiBubur-Daun-Kelor-Instan. Didownload pada tanggal 11 Desember 2018

[3] Wiyanti, Widiya. 2018. Kandungan Daun Kelor yang Sangat Bermanfaat Bagi Kesehatan. https://m.detik.com/health/berita-detikhealth/d-

3857741/kandungan-daun-kelor-yang-sangat-bermanfaat-bagikesehatan. Didownload pada tanggal 13 Desember 2018

[4] Lussy, N.D. and Rihi, M.S.R., 2018. IbM KELOMPOK TANI TANAMAN PANGAN DAN SAYURAN DI KELURAHAN KOLHUA. J-Dinamika, 3(1).

[5] Djamila, S., Budiati, T. and Bahariawan, A., 2016 PERBAIKAN PROSES PEMBUATAN BAKPAO SEHAT DAN NIKMAT DI KELOMPOK PENGUSAHA BAKPAO TEGAL BESAR-JEMBER. J-Dinamika, 1(2). 